\title{
The Time Value and Implementation Strategy of Rural Points System
}

\author{
Wanda Sang1,2 \\ ${ }^{1}$ School of Marxism, Shaanxi University of Science \& Technology, Xi'an, China \\ ${ }^{2}$ Research Center of Shaanxi Rural Grass-Roots Party Organization, Xi'an, China \\ Email: 441098186@qq.com
}

How to cite this paper: Sang, W. D. (2022). The Time Value and Implementation Strategy of Rural Points System. Open Journal of Social Sciences, 10, 276-289. https://doi.org/10.4236/jss.2022.101023

Received: December 21, 2021

Accepted: January 21, 2022

Published: January 24, 2022

Copyright $\odot 2022$ by author(s) and Scientific Research Publishing Inc. This work is licensed under the Creative Commons Attribution International License (CC BY 4.0).

http://creativecommons.org/licenses/by/4.0/

\begin{abstract}
This paper aims to clarify and explore the contemporary value and effective strategies for the rural point system through policy analysis and literature research and provide theoretical explanations and countermeasure suggestions for its implementation. The rural points system is created in the dual variation of rural social structure, cultural concept, value identity transformation and grass-roots governance model transformation. It is the sum-up of governance experience and thought innovation of mass autonomy under the leadership of grass-roots party organizations, and constructs good governance and good discipline scheme for rural life. To fully implement the rural points system, we should grasp the dual values. First, we should promote the modernization of rural governance system and governance ability from the aspects of grass-roots party construction guidance, governance system construction and governance efficiency transformation. Second, we are supposed to focus on such key elements as rural industry, ecology, rural lifestyle, governance and living, and help promote rural revitalization as well as accelerate agricultural and rural modernization. To fully implement the rural points system, we should adopt effective strategies to reconstruct the main body of rural points governance by maintaining and respecting the practical interests, initiative and reasonable demands of the masses of farmers. By strengthening the integration of information technology and media technology, to improve the governance system integrating rural integral government services, governance information transmission, and the expression of governance demand. By improving the farmers' self-government system, we will mainly assess village public affairs, villagers' governance rights and rural points achievements, and innovate the points governance mode of "jointly construction, co-governance and sharing".
\end{abstract}

\section{Keywords}

Rural Points System, Grass-Roots Party Construction, Rural Governance, 


\section{Introduction}

Since the 19th national congress, the CPC Central Committee has made a series of important statements and clear stipulations on rural governance, which has involved an evolution process from top-level design, comprehensive deployment to the promotion of local governance experience. The report of the 19th National Congress takes "effective governance" as one of the general requirements of the Rural Revitalization Strategy, and also puts forward "improving the rural governance system combining autonomy, rule of law and rule of virtue" (The 19th National Congress of CPC, 2017). The third, fourth and fifth plenary sessions of the 19th CPC Central Committee proposed to enhance local governance capacity, "build a simple and efficient grass-roots management system" (Third Plenum of the 19th CPC Central Committee, 2018); promote the modernization of national governance system and governance capacity, "adhere to and improve the social governance system of jointly building, co-governance and sharing" and "build a new pattern of grass-roots social governance" (Fourth Plenum of the 19th CPC Central Committee, 2019); We will promote rural construction and "realize the effective connection between consolidating and expanding the achievements of poverty alleviation and Rural Revitalization" (Fifth Plenum of the 19th CPC Central Committee, 2020). In July 2020, the notice of the Ministry of agriculture and rural areas of the office of the Central Rural Work Leading Group on the promotion and application of the points system in rural governance required that "the points system should be promoted and applied in rural governance according to local conditions" (The Office of Central Rural Work Leading Group \& Ministry of Agriculture and Rural Affairs, 2020), and attached are Fengxian District of Shanghai, Guyuan City of Ningxia Hui Autonomous Region, Fucheng town of Jiyuan City, Henan Province, Tongjie Village of Pinghu City, Zhejiang Province, You Xiqiao village of Xinhua County, Hunan Province, eight typical cases, etc. It can be found that strengthening the experience summary and theoretical exploration of rural governance, especially the system construction and implementation strategy of rural governance, has become an important topic of the times.

There is an endogenous interactive development relationship between rural governance and grass-roots party construction. Promoting their integration, empowerment and innovation has become the value proposition and practical approach to comprehensively promote rural revitalization. Grass-roots party construction has become the core variable of rural governance. It has political and organizational advantages, which can overcome the governance difficulties such as weakening of the main body, insufficient power and limited means, help to give play to the role of organizing and mobilizing the masses, leading the 
model and reshaping the subjectivity and publicity of governance (Zhang, 2021), promote the transformation of governance efficiency and implement governance measures. Rural governance is an important starting point for the innovation of grass-roots party construction. Specific governance matters can optimize the path of grass-roots party organization construction, promote the extension and refinement of grass-roots party construction, and are beneficial for participatory and service-oriented party construction $(\mathrm{Qu}, 2021)$. It can help to practice the original intention and mission in governance services, and enhance Party members' political beliefs, ideals and beliefs, identity awareness and organizational discipline so as to make them better serve the mass farmers.

Rural points system is the summary of governance experience and innovation of thought of mass autonomy under the leadership of grass-roots party organizations. The rural points system is created and operated in the dual variation of the transformation of rural social structure, cultural concept, value identity and grass-roots governance model. Traditional rural governance focuses on the construction of grass-roots administrative system, functional orientation and project implementation, resulting in the suspension and idling of state power and policies, forming the involution of rural governance. The rural points system adapts to the changes of rural political power construction and governance plan, focusing on the governance space of public communication, public (collective) affairs, the impact of modernity and farmers' identity and other core issues, sink grassroots governance power, release governance vitality, aggregate governance power, follow the action logic of system-governance-life, promote the evolution of governance subjects from normative restraint mechanism to trust and cooperation mechanism, and focus on system construction and transformation of governance efficiency on the basis of the dual joint force of policy incentive and practical exploration so as to construct good governance and good order scheme of rural life. Therefore, clarifying and elucidating the contemporary value of the rural point system can help lead the new rural governance; exploring and adjusting the main strategies for implementing the rural point system can help strengthen the effectiveness of rural governance.

\section{The Time Value of the Implementation of Rural Points System}

The creation, operation and implementation of the rural points system have distinct requirements of the times, policy background, institutional environment and relatively stable rural social conditions, highlighting the dual values of the times: firstly, it is embedded in the unique context of the modernization of national governance system and governance ability, which has become the summary and innovation of rural governance experience; Second, in line with the Rural Revitalization Strategy, it has become the internal requirement and powerful starting point for realizing industrial prosperity, ecological livability, rural civilization, effective governance and rich life. 


\subsection{Promote the Modernization of Rural Governance System and Governance Capacity}

Rural governance, as the basic force of national governance system and governance capacity-building, by giving full its role, can make the country (administrative) governance ability and grass-roots autonomy ability blend, and social participation and villagers' participation interact positively, so as to achieve farmers' self-management, self-service, self-education and self-supervision under the leadership of grass-roots party organizations. The rural points system is the innovation in the concept, ideas and methods of grass-roots governance, which promotes the institutional and operational model of grass-roots political power construction to systematic and service-oriented governance, enhance the institutionalization, modernization and living of grass-roots social governance, and then provide accurate and refined services, so as to meet the endogenous governance needs of rural society.

Firstly, grass-roots party building leads rural governance. Grass-roots party organizations are the core force of rural governance. We should pay attention to the combination of governance ability improvement and cadre team construction, establish the concept of rural social governance and service, constantly adjust the relationship between the party and the masses, regulate social order, and give play to the function of political construction and serving the masses around rural governance. The rural points system is promoted and implemented under the overall leadership of village level party organizations, giving full play to the appeal, organization and mobilization of party organizations, and the party members mobilize the farmers to participate in the points system, so as to enhance the relationship between the party and the masses as well as the farmers' sense of belonging and unity.

Secondly, strengthen the institutionalization of rural governance. The rural points system is a flexible system different from the previous administrative (management) system, which combines the daily production and life of the masses and the public (collective) large and small affairs, then transformed into specific and quantifiable points. Open and transparent detailed rules for granting points have been established, and specific rules, regulations and rules have been formulated to ensure the institutional supply of rural governance and form an effective and long-term operation mechanism. The rural points system has a complete set of scientific norms, legal and reasonable systems, including point granting system, execution system, management system and audit system, evaluation system and supervision system, etc. The package improves and optimize various systems, promote rural governance with institutional provisions, clarify and improve the channels for villagers to participate in governance, give play to the tension and limit in the governance function field, release the vitality of rural governance, consolidate the villagers' sense of identity with the state power and enhance the villagers' sense of acquisition in daily life.

Thirdly, improve the transformation of rural governance efficiency. Rural go- 
vernance requires the transformation of institutional and policy advantages into executive advantages to show effective governance. The key lies in governance ability and executive ability. The rural points system takes the transformation of governance efficiency as an important starting point. On the one hand, it improves the administrative ability, organizational ability, governance ability and executive ability of the governance body. On the other hand, it improves the working system to strengthen the implementation of the system through supervision and supervision. In other words, accelerate the construction of governance bodies (teams), make good use of institutional stock resources, and make the "built" pragmatic system "operating" efficiently (Zhang, 2019).

\subsection{Promote the Effective Implementation of Rural Revitalization}

Rural governance is the basic task of comprehensively promoting rural revitalization, an important focus of the regionalization practice of rural revitalization, and is vital to the effectiveness of rural revitalization. On the one hand, the effective implementation of the rural points system has become the basis and premise of the five rural revitalization tasks, namely industrial revitalization, talent revitalization, cultural revitalization, ecological revitalization and organizational revitalization. On the other hand, the implementation of rural points system is embedded in the five general requirements of rural revitalization and has become the fundamental path to achieve industrial prosperity, ecological livability, effective governance, rural civilization and rich life. In addition, the value pursuit of rural points system converges with the five requirements, and is based on the dominant position of farmers; The action objectives are consistent with the five requirements to realize the farmers' vision of a better life; The setting of evaluation content, mechanism and institution construction and implementation path is intertwined and superimposed with the five requirements.

First, industrial prosperity is the foundation of rural revitalization. The rural points system establishes relevant indicators for industrial prosperity, refines various points items, and scientifically grants points, such as advocating the development of industries to get rich and expand the scale of industries; Encourage the introduction of investment to develop the industry of the local village; Encourage participation in industrial skills and labor skills training to provide scientific and technological support for industrial development; Encourage rich pioneers to lead others to develop industries; Encourage young graduates and migrant workers to return home and start businesses, and rely on talents to promote the industry development. The implementation of this series of positive incentive items will promote the adjustment, optimization and upgrading of rural industrial structure.

Second, ecological livability is the key to rural revitalization. Through the implementation of the points system, we establish a point card for each household, set up options such as family health evaluation and beautiful rural construction, promote pollution control, residential environment improvement and ecological 
environment protection, solve problems such as livestock and poultry manure pollution, crop straw and domestic waste, improve rural environmental sanitation, optimize the landscape environment, attract tourists, and then provide sightseeing, leisure, health preservation and other special services so as to build rural ecotourism demonstration villages and towns.

Third, rural civilization is the guarantee of rural revitalization. On the one hand, the points system relies on township regulations and people's conventions, sets up extra points and deduction items, promotes good deeds and righteous deeds, punishes immoral and anomie behaviors imperceptibly improves farmers' ideological and moral quality and scientific and cultural literacy, revitalizes rural virtue culture, and highlights the appeal, cohesion and vitality of local culture; On the other hand, setting up incentive mechanism, improving villagers' sense of responsibility and collective consciousness, and mobilizing villagers to participate in village collective affairs will help to strengthen village collective construction. In this way, we can comprehensively promote the transformation of customs in rural areas and cultivate good family style, simple folk style and civilized rural style.

Fourth, effective governance is the basis of rural revitalization. The rural points system has formed a governance system of village "two committees" organizational leadership, social coordination, villagers' participation and joint inspection and supervision. In the process of implementation, party members and cadres take the lead in publicity, guidance and demonstration, showing the leadership and organizational strength of grass-roots party organizations, playing a pioneering and exemplary role, and strengthening the villagers' awareness of participation and ownership, effectively give full play to the functions of villagers' self-organization, self-management and self-service, promote the construction of mass autonomous organizations, and improve the rural governance system combined with materialized autonomy, rule of law and rule of virtue.

Fifthly, affluence is the goal of rural revitalization. In the crucial stage of poverty alleviation, each village promotes the model of the point + poverty alleviation (Tang \& Zhou, 2021), files and cards for all kinds of poor households, sets up all kinds of self-help projects, and encourages assistance among neighbors and village groups to achieve poverty alleviation and prosperity. In the current stage of accelerating agricultural and rural modernization, the rural points system has improved the villagers' production and living standards. The first is the basic category. Each village universally implements the points supermarket model. Villagers can exchange goods in love supermarkets, points savings station, moral banks and so on. Second, advanced villages with rapid economic development have launched the points + collective economic model, and villagers participate in the village collective economic dividends through points and become shareholders. In the mode of points + financial institutions, villagers can enjoy preferential loan limit by virtue of points. In other words, the rural points system cultivates the value concept of villagers' development and common 
prosperity, as well as stimulates villagers' enthusiasm for self production and participation in the development of village collective economy which will help to form a vivid scene of villagers' affluence and village development.

In short, we should highlight the value of the times, follow the logic of governance, and improve the efficiency of governance in implementing the rural point system. On the one hand, we should take measures to stimulate villagers to participate in rural affairs (Liu, 2020). Different regions should take different measures to improve the system and promote the modernization of the governance system and governance capacity; on the other hand, in the concrete implementation process, we should find the right target and make up for the shortcomings; focus on the governance structure and elements, develop industries, talents, promote excellent village culture, optimize ecology and organization; improve the point index, and precise the points to promote rural revitalization.

\section{Strategies for Rural Point System}

\subsection{Reconstruct the Governance Subject of the Rural Point System, and Activate the Internal Driver for Rural Governance}

The construction of governance subjects is the top priority of rural governance, reshaping the multiple governance subjects, clarifying the role and function of governance subjects, adjusting the relationship between governance subjects, and promoting the advantages of governance subjects to achieve mutual assistance and greater coordination with complementarity. Therefore, the rural point system is to construct the multiple governance subjects and follow the adaptive and flexible operating mechanism of governance, to win the support both from government and rural people, building a type of grass-roots governance in rural areas. On one hand, it is necessary to effectively strengthen the force of governance subjects, improve interagency coordination, combine major residency secretary, college graduates working as village officials, sci-tech experts, agri-tech extension staff with technical information, media communication, and other social and organizational elements together, so as to form an organic unity and strengthen the interaction between the government and society. On the other hand, it is of importance to improve the organic integrity of internal governance subjects, give full play to the governance of the village party branch and village committee, party cadres, new rural elites as well as the ordinary rural people, and break the dilemma of both collective action and autonomous action, in order to achieve the coordinated governance of multiple governance subjects $(\mathrm{Hu}$, $\mathrm{Du}, \& \mathrm{Yu}, 2019)$.

The implementation of the rural point system should give full expression to the rural people as the center of the governance. Firstly, according to the rural point system, everything should be committed to doing for the rural people, and their real interests should always be considered and guaranteed. The system should integrate decision-makers, followers, as well as implementers, change the 
logical thinking of others and self, unify the action mode, provide high-quality services for rural people, expand their public (collective) life space, and improve their life quality and inner world (Wang, Hao, \& Wang, 2021). Concretely speaking, guided by a vision of putting the rural people as the top priority of the governance, the rural point system should be linked to the vital interests of villagers, focus on their lives and the actual development, and change their thoughts and behaviors. In addition, their contributions to public affairs in the rural areas can be transformed into points in the poverty registration, which makes the points become a symbol of honor and identity of the rural people. By virtue of the points, they can exchange daily necessities at the designated supermarkets to gain benefits.

Secondly, the rural point system should go deep into the rural people, and respect their desires and reasonable demands. In accordance with the system, the urgent requirements in rural people's actual lives should be linked to public policy decisions, public services, and public goods supply. And it is necessary to take rural people's lives into consideration, effectively solve their problems in daily trifles, improve neighborhood relations, and guarantee a stable life. In fact, the underlying reasons for problems in villagers' daily trifles lie in various conflicts of interest. As a result, the rural point system is established to promote the feedback of well-being issues, resolve contradictions and disputes, orderly safeguard self-interests, and maintain a positive development of basic public rights, reflecting the fair, just, democratic value judgments and selections.

Thirdly, the implementation of the rural point system must rely on rural people and respect their pioneering spirits. The rural point system must build multiple governance subjects putting the rural people first, empower villagers to blaze new trails, inspire them to take the initiative, and stimulate individual autonomy, allowing rural people to get points, add points and accumulate points. Moreover, the system should encourage villagers to gather strengths, change passive action to active action, make rural people keen on public (collective) affairs in rural areas, and transform the previous outsiders into active participants involved in those affairs.

Fourthly, owing to the rural point system, rural people should be guided to forge ahead in the right direction. From the perspective of the whole operating process of the rural point system, grass-roots political authority, the village party branch, and village committee ought to play important roles in decision-making, management, guidance, and services of the governance. For instance, they should exert important influences on the comprehension and control of the related lines, principles, and policies of the governance, the discussion on the combination, transformation, and complementation between the top-level design and local cases, the optimization and allocation of the governance resources, the building, regulation and coordination of the specific governance system, as well as the organization and mobilization of rural people. From the perspective of the governance efficiency, the village party branch and village 
committee should play a fighting forceful role to form the concrete organizational model, improve the system rules, supervision and regulation, attach importance to the efficiency of participants, promote the standardized, routinized, and regularized construction of the rural point system, and put spurs to more extensive participation and governance of the rural people.

\subsection{Strengthen the Integration of Rural Integral Governance Technology to Build an Information and Intelligent Governance System}

Governance technology is the technical support and efficiency guarantee for the operation of the governance system and is the symbol of modernization of the governance system, which helps transform the governance mode and improve the energy efficiency of governance. Governance technology is divided into information technology and media technology. Information technology mainly includes the Internet of Things, big data, cloud computing, blockchain, artificial intelligence, etc. It is responsible for forming the technical architecture of the governance system, building the governance network, optimizing governance platform and interface, helping to apply the underlying technology to the regulation and governance mechanism, and promoting the informationization, intelligence, and efficiency of the rural governance system, operation mechanism, and workflow (Liu \& Zeng, 2020). Media technology mainly refers to official media publicity technology and farmers' mass self-media technology, such as public numbers, microblogs, short video, mobile webcasting, etc., with governance functions such as information transmission, cultural dissemination, value guidance, political identity, and public opinion supervision (Shan \& Shan, 2020). The innovation of media technology promotes the transformation of governance from a section-based administrative type to a mediated communication type of governance, forming a governance pathway of participatory communication and external communication, promoting the circulation and sharing of public information and public resources, improving social relations in rural areas, effectively conveying governance power and public authority, and enhancing the mobilization capacity of publicity organizations.

The rural point system should adhere to the scientific governance technology concept. The concept of governance technology integrates governance philosophy and governance technology logic. The use of rural governance technology should adhere to the unity of instrumental rationality and value rationality, combine information technology and media technology, and improve governance efficiency; at the same time, the governance concept is integrated into the technical logic, so that the integral governance methods become more "scientific" and benefit villagers' self-governance.

First, information technology helps refine the spatial structure of rural governance and meet more governance needs. The scattered rural villages, the differentiation of social structures, and the discrete state of social members have caused the disintegration of traditional village communities. The interests, value 
choices, and behavioral patterns of elites, general villagers, and migrant workers are very different, which reduces the operation and service efficiency of the village point system, becoming a difficult governance problem. Information technology, as a supporting technology for the rural point system, can establish a basic organic structural framework that can ensure the daily implementation of the governance system; as the linkage technology of the rural point system, it can establish several point unit networks to form effective grid management; as the service technology, it can build an instant, dynamic and convenient point management service platform, so that people can handle various affairs through this platform only. Second, information technology helps enhance the deployment and supervision of rural integral governance rights. On the one hand, it clarifies and standardizes the administrative force and governance power from the technical level, sets up each power operation point of the point system, coordinates the allocation of power and responsibility among various levels, and avoids centralization of governance subjects (Wang \& Du, 2021). On the other hand, it sets options related to integral governance, adds assessment standards related to villagers' rights and interests, reshapes institutionalized and rule-based governance, carries out supervision and prevention and control, and avoids the arbitrariness of some cadres in the process of governance. Third, media technology can help promote rural integral governance cases and enhance the communication effect. The countryside through the media can tell new vernacular stories, spread vernacular spirit and positive energy, and visualize governance effects. As can be seen, the integration of information technology and media technology to create an intelligent network interactive governance (management) platform and a diversified network live platform helps improve the technical governance system integrating rural integral government services, governance information transmission, and the satisfaction of governance demand.

\subsection{Innovate the Rural Point Governance Model of Joint Contribution, Joint Governance and Shared Benefits}

The rural point governance model is undergoing a new change, evolving from the traditional constraint management and service governance to the current community governance. Compared with traditional rural governance, community governance is oriented to resource integration, subject construction, and social projects. Its technical means of governance, service methods, and strategies have become more precise, targeted, and efficient. This new rural governance model is committed to building a rural governance community, in which each villager should be clear about his or her responsibilities, do his or her part, and ultimately enjoy the shared benefits.

The self-governance system of rural people needs to be improved in the rural point system. According to the Decision of the Fourth Plenary Session of the Nineteenth Central Committee, the self-governance system of rural people has two meanings: one is to implement the self-governance system, namely, selfmanagement, self-service, self-education, and self-supervision; the other is to 
promote the building of direct democracy at the grass-roots level based on self-governance system of rural people. Therefore, advancing the villagers' self-governance is the main task of the rural point system. Members of the village party branch and village committee should empower the rural people to enhance their awareness of self-governance and clarify the relationship between rights, duties, and interests. At the same time, they should focus on improving the point system to form a relatively stable, highly energetic, and effective basic institutional framework, which is conducive to the realization of broad participation and autonomous self-governance of rural people. The rural point system should help build a grass-roots consultative democracy system (Xinhua County Committee, 2019).

The point system follows the principles of "the people choose the decision", "the people make the regulations" and "the people decide the result". Under the rural point system, villagers can independently express their opinions and consult with each other, and the final result will be agreed upon by the villagers, which ensures their rights and subjectivity of them. At the same time, the supervision between villagers should be enhanced to ensure the standardized operation in each process, including registration, review, public announcement, calculating, evaluation, reward, and punishment. Points information and evaluation results should be regularly publicized to make villagers more satisfied. The rural point system is committed to creating a governance platform at the grass-roots level of joint contribution, joint governance and shared benefits. Joint contribution refers to the participation of all villagers in the economic construction of the village. Backward villages need to set up a happiness point program, to mobilize villagers' enthusiasm and allow them to gain wealth through their hardworking. In addition, the rural point system in agricultural business and college students returning to their hometowns to start their businesses should also be improved to motivate social elites, youth groups, and other rural elites to devote themselves to revitalizing the rural economy. Joint governance refers to villagers' joint governance of the grass-roots community. The rural point system is dedicated to guaranteeing the exercise of villagers' rights to governance. Villagers' participation in grass-roots governance enhances their sense of ownership. Therefore, villagers pay more attention to the rights, such as the right to know, the right to participate, the right to express, and the right to supervise. Under the principle of "everyone's business can be run and managed by everyone", village affairs are discussed by villagers' representatives and then voted on together in the village assembly. Shared benefits mean that all villagers can receive material rewards. Under the point system, villagers can not only exchange their accumulated points for rewards, such as daily necessities but also participate in the village collective income sharing to promote village governance and development. The rural point system also helps to improve personal quality. The contributions and honorable deeds people did are recorded and then publicized, popularizing social virtues to the public (Kong, 2020). Based on 
the main connotation of joint contribution, joint governance, and shared benefits, the rural point system should be preserved and passed on as a village treasure to provide benefits to the next generation.

It can be seen that optimizing the rural point system based on three dimensions of governance subjects, governance techniques, and governance modes provides a useful countermeasure for the universal and comprehensive implementation of the village point system. In addition, reconstructing multiple governance subjects with the rural people as the core position and promoting the transformation of the peasant masses from participation in governance to active and self-governance can help strengthen policy implementation, mobilize more villagers, and improve governance efficiency; deepening the integration of information and media governance technology can help adjust the structure of governance space, enhance the deployment and supervision of governance rights, strengthen the propagation of governance cases and the construction of the image of the countryside; innovating the governance model of "joint contribution, joint governance, and shared benefits" can mobilize the internal elements and resources of rural governance and development, improve the governance capacity of grass-roots organizations, build a community of rural governance and development, and activate the endogenous power of the community.

\section{Conclusion}

Theoretical research and local practice of the rural point system needs to be further explored. How to scientifically and effectively promote the use of the rural point system is an ongoing research topic. The rural point system has created a new governance model of "joint contribution, joint governance, and shared benefits", which can contribute to rural revitalization. The implementation of the point system should not only meet the basic policy, i.e., to promote the modernization of the rural governance system and governance capacity, but also meet the new requirements of local social development, which highlights its applicability and effectiveness. In addition, it should also deal with the inherent relationship with village and township grass-roots party development, administrative services, industrial prosperity, and the construction of village rules and regulations; coordinate and solve the basic problems in rural governance, such as conflicts in interpersonal relations and various kinds of interest disputes, etc. In short, the implementation of the village point system should be scientifically based on classic cases from various regions, and constantly improve and innovate to find a suitable governance method for the village. It involves two aspects: points and technology. On the one hand, enrich the content of points, update the criteria of points, make the assignment and deduction of points more reasonable; optimize the form of points, improve the evaluation system of points, so that farmers have a greater sense of achievement, acquisition, and belonging. On the other hand, strengthen technical support, use information technology, such as the Internet of Things, big data, blockchain, etc. to build governance net- 
works, optimize governance platforms and interfaces, while empowering villagers' autonomy, refining governance rights and obligations, and improving governance capacity; use media technology, such as public numbers, microblogs, short video, mobile live streaming, etc. to strengthen public supervision and improve the ability to organize and mobilize villagers. In addition, a regular implementation mechanism should be established. Administrative organizations at the provincial, municipal, county, and village levels should clarify their respective responsibilities and collaborate to form a new pattern, in which provincial policies play a leading role, municipal and county administrators should put the policies into practice, and village and town cadres should mobilize all villagers to participate, promoting the points system to take root in the countryside and integrate with local culture.

\section{Conflicts of Interest}

The author declares no conflicts of interest regarding the publication of this paper.

\section{References}

Fifth Plenum of the 19th CPC Central Committee (2020). Suggestions of the Central Committee of the Communist Party of China on Formulating the 14th Five Year Plan for National Economic and Social Development and the Long-Term Objectives for 2035 (p. 22). People's Publishing House.

Fourth Plenum of the 19th CPC Central Committee (2019). Communique of the Fourth Plenary Session of the 19th Central Committee of the Communist Party of China (pp. 13-14). People's Publishing House.

Hu, W. W., Du, Y. Q., \& Yu, S. (2019). Three Dimensions of Rural Flexible Governance: Power, Discourse and Technology. Learning and Practice, No. 1, 20-28.

Kong, X. X. (2020). Exploration and Enlightenment of "Points System" of Grass-Roots Social Governance in the New Era. Rural Areas, Agriculture, Farmers (Version B), No. 2, 37-38

Liu, J. X., \& Zeng, S. (2020). Intellectual Properties, Top-Level Design and Exploration Practice of Digital Governance in Rural Areas of China. Journal of Lanzhou University (Social Science Edition), 48, 64-71.

Liu, X. J. (2020). From Institutional Arrangement to Actual Operation: The Dilemma of the Point System and Its Generative Logic-An Analysis Based on the Research of Ezhong T Village. Journal of Gansu Administrative College, No. 6, 80-90.

Qu, X. (2021). Analysis on the Types of Grass-Roots Party Construction and the Practical Mechanism Leading Rural Governance in the New Era. Journal of China Yan'an Cadre College, 14, 87-94.

Shan, J. Y., \& Shan, L. C. (2020). Problems and Countermeasures of Rural Social Governance Innovation in the New Media Environment. Leadership Science, No. 4, 110-113.

Tang, K., \& Zhou, Y. (2021). Research on the Internal Mechanism and Realization Mechanism of Points System Promoting Rural Revitalization. Rural Areas, Agriculture and Farmer (Version B), No. 6, 4-7

The 19th National Congress of CPC (2017). Decisive Victory in Building a Well-Off Society in an All-Round Way and Winning the Great Victory of Socialism with Chinese 
Characteristics in a New Era-A Report at the 19th National Congress of the Communist Party of China (October 18, 2017) (p. 32). People's Publishing House.

https://doi.org/10.18013/jnar.2017.32.2.007

The Office of Central Rural Work Leading Group \& Ministry of Agriculture and Rural Affairs (2020). Notice of the Central Rural Work Leading Group Office and the Ministry of Agriculture and Rural Areas on the Promotion and Application of the Points System in Rural Governance.

http://www.moa.gov.cn/nybgb/2020/202008/202010/t20201020_6354684.htm

Third Plenum of the 19th CPC Central Committee (2018). Decision of the CPC Central Committee on Deepening the Reform of Party and State Institutions. http://www.gov.cn/zhengce/2018-03/04/content_5270704.htm

Wang, G. Q., \& Du, Y. K. (2021). The Construction of "the Integration of Self-Governance, Rule of Law and Moral Governance" Rural Governance System under Technology Empowerment-A Case Study Based on F County in Northern Jiangsu. Social Science Research, No. 5, 124-133.

Wang, Z., Hao, W., \& Wang, W. C. (2021). What Makes Rural Point System Governance Successful-A Case Study Based on Gu Village. Journal of Shanxi Agricultural University (Social Science Edition), 20, 53-62.

Xinhua County Committee (2019). Leveraging the "Great Power of Self-Improvement and Development" with Small Points-Exploring the Evaluation Management of Village Level Affairs in You Xiqiao Village, Xinhua County, Hunan. Rural Work Newsletter, No. 16, 42-43.

Zhang, R. J. (2021). Research on the Promotion of Rural Governance Efficiency Driven by Grass-Roots Party Construction in the New Era. Huxiang Forum, 34, 48-57.

Zhang, S. (2019). How to Transform from Institutional Advantage to Governance Efficiency. Guangming Daily News. 